\title{
Morphological and molecular identifications of three native arbuscular mycorrhizal fungi isolated from the rhizosphere of Elaeis guineensis and Jatropha curcas in Indonesia
}

\author{
MARIA VIVA RINI ${ }^{1, \boldsymbol{\nu}}$, FITRI YELLI ${ }^{1}$, DARWIN LEONARDO TAMBUNAN ${ }^{1}$, INGGAR DAMAYANTI ${ }^{2}$ \\ ${ }^{1}$ Department of Agronomy and Horticulture, Faculty of Agriculture, Universitas Lampung. Jl. Prof. Dr. Sumantri Brojonegoro No. 1, Bandar Lampung \\ 35145, Lampung, Indonesia, Tel./fax.: +62-721-702673, `email: maria.vivarini@fp.unila.ac.id \\ ${ }^{2}$ Department of Forestry, Faculty of Agriculture, Universitas Lampung. Jl. Prof. Dr. Sumantri Brojonegoro No. 1, Bandar Lampung 35145, Lampung, \\ Indonesia
}

Manuscript received: 11 July 2021. Revision accepted: 22 October 2021.

\begin{abstract}
Rini MV, Yelli F, Tambunan DL, Damayanti I. 2021. Morphological and molecular identifications of three native arbuscular mycorrhizal fungi isolated from the rhizosphere of Elaeis guineensis and Jatropha curcas in Indonesia. Biodiversitas 22: 4940-4947. Molecular analysis has been widely used to provide more accurate identification within arbuscular mycorrhizal fungi (AMF) species than identification based on morphology. However, morphological analysis is essential for a basic preliminary of classification studies. Therefore, a study is needed to complete the identification of AMF isolates through morphological and molecular analyses. This research used three AMF isolates, namely MV 5, MV 17, and MV 18, which were isolated from Indonesian agricultural land. Sporebased taxonomy (shape, size, color, ornamentation, PVLG, and Melzer's reaction) and fungal colonization on roots of maize trap plants were employed for the morphological studies. AMF species identification was performed using molecular analysis through nestedPolymerase Chain Reaction (PCR) to amplify a fragment of SSU rRNA followed by sequencing and phylogenetic tree construction. Morphological analysis showed that MV 5 had spores borne from the neck of the sporiferous saccule, MV 17 was found to have a bulbous suspensor without a germination shield, and MV 18 had spores borne from subtending hyphae. The SSUR rRNA analysis revealed that MV 5, MV 15, and MV 18 were identified as Acaulospora longula, Gigaspora margarita, and Glomus etunicatum, respectively. Both morphological and molecular methods demonstrated reliable and consistent results that complement AMF taxonomy studies.
\end{abstract}

Keywords: AMF structure, arbuscular mycorrhizal fungi, molecular, morphology

Abbreviations: AMF: Arbuscular mycorrhizal fungi; SSU rRNA: Small subunit rRNA, ITS: Internal transcribed spacer

\section{INTRODUCTION}

Arbuscular mycorrhizal fungi (AMF) are one of the mycorrhizal types which can form internal and external hyphae structures that are beneficial for plants because they can improve the nutritional status of the plant and soil characteristics (physical, chemical, and biological) (Smith and Smith 2012; Bücking and Kafle 2015; Chen et al. 2018). AMF enhances nutrient uptake and allows plants to be more tolerant against drought, salinity, and other environmental stress (Syafruddin et al. 2016; Duc et al. 2018; $\mathrm{Hu}$ et al. 2021). Moreover, AMF is capable of protecting roots from pathogenic attack within the soil, improving plant growth and yield, and fixed solubilizing phosphate in soil (Prasetya and Anderson 2011; Rini et al. 2020).

The effectiveness of AMF is influenced by the types of the host plant and mycorrhizae (Ijdo et al. 2011; Selvakumar et al. 2018; Melo et al. 2019). To successfully obtain higher effectiveness of AMF application, the utilized species needs to be determined. Therefore, identification of AMF species is a crucial step prior to field application, especially in the application of different species within the same genus of AMF. A study by Rias et al. (2014) used three species of Glomus sp. (MV 4, MV 11, and MV 13 on oil palm (Elaeis guineensis Jacq.) seedlings and reported that MV 4 and MV 13 isolates showed a good ability to enhance the growth of oil palm seedlings, while MV 11 did not show any benefits to the plant. It suggests that three different species of Glomus sp. have different performances to the plant. Relying solely on genus data is insufficient to find the best host for AMF isolates. Hence, molecular analysis is very important for determining AMF species and plays a crucial role in maximizing their potential for agricultural applications.

Spore morphological characters were used to identify arbuscular mycorrhizal fungi before the molecular approaches were widely employed. The AMF was divided into three families (Acaulosporaceae, Gigasporaceae, and Glomeraceae), six genera (Acaulospora, Entrophospora, Gigaspora, Glomus, Sclerocystis, and Scutellospora), order Glomerales by Morton and Benny (1990), and placed in Phylum Zygomycota (Schenk and Perez 1990; Morton and Benny 1990; Oehl et al. 2011). This method is commonly used because it is easy, fast, cost-effective, and can identify up to the genus level. However, it is not easy to identify up to the species level as spore morphology cannot be relied on to identify many AMF species with similar features. For 
example, an observation of a very thin wall layer needs a spore to be in good condition when mounted onto objectglass, which is difficult to do, especially for the big-size spore.

Furthermore, most spores from the field are not in good condition and are difficult to identify based on their morphology because some spores are mostly found in damaged conditions, and their traits are separated from the spore (Krüger et al. 2012; Souza 2015). The major taxonomic change in AMF occurs as soon as molecular phylogenetic tools have become available based on the nuclear ribosomal RNA (rRNA) gene regions as a marker of AMF (Krüger et al. 2012; Redecker et al. 2013). Molecular identification provides more accurate, highly specific, and fast results. Its application to a specific region in fungal DNA allows species identification by using welldeveloped techniques, including polymerase chain reaction (PCR) (Oehl et al. 2011 Redecker et al. 2013; Souza 2015).

The current modern classification of Glomeromycota is based on a consensus of regions spanning ribosomal RNA genes: 18S (SSU), ITS1-5.8S-ITS2 (ITS), and/or 28S (LSU) which was proposed by Redecker et al. (2013). SSU rRNA gene has been the most chosen in AMF identification due to the availability of primer pairs and has a highly conserved gene (Victorino et al. 2020). Consequently, we selected the $18 \mathrm{~S}$ rRNA gene for molecular identification of AMF in the study. Although molecular analysis provides precise and specific results, spore morphology is still an important stage for AMF identification to complete the results of molecular identification (Covacevich et al. 2021). In addition, AMF morphology analysis is also essential for basic science purposes, especially when using AMF to be developed into biofertilizers which requires detailed traits information. The morphological analysis allows identifying the characteristics of AMF spores, while molecular analysis identifies the species and taxonomy position. Thus, both methods are necessary to create a complete and successful taxonomy of AMF.

In this study, we identified three native AMF spores (MV 5; MV17; MV18) from the rhizosphere of oil palm (E. guineensis Jacq.) and Jatropha curcas L. plant in
Indonesia based on spore morphology and 18S rRNA gene sequences of fungi as molecular analysis to identify the AMF species.

\section{MATERIALS AND METHODS}

\section{Morphological analysis}

Three AMF isolates were used in this study. MV 5 was isolated from the oil palm rhizosphere in North Sumatera, Indonesia (-8 $\left.17^{\prime} 49.4^{\prime \prime} \mathrm{N} 113^{\circ} 34^{\prime} 00.6^{\prime \prime E}\right)$ while MV 17 and MV 18 were isolated from Jatropha rhizosphere in East Java, Indonesia $\left(3^{\circ} 24^{\prime} 00.6^{\prime \prime} \mathrm{N} 98^{\circ} 42^{\prime} 45.6^{\prime \prime} \mathrm{E}\right)$. All three isolates were preserved in the Plantation Production Laboratory, Lampung University, Indonesia (Figure 1). Since 2011, these three isolates have been used in the greenhouse of Faculty of Agriculture, University of Lampung and have promoted crop growth (Rini et al. 2017; Rini et al. 2020) and produced high spore density. Morphological identification of AMF was carried out by isolating spores from MV 5, MV 17, and MV 18 using wet-sieving and decanting methods on various sieve sizes, i.e., $45 \mu \mathrm{m}, 90$ $\mu \mathrm{m}, 150 \mu \mathrm{m}, 250 \mu \mathrm{m}$, and $500 \mu \mathrm{m}$. Spores were transferred to the Petri dishes and observed under a stereomicroscope with a magnification of $45 \mathrm{x}$ for identification of spore morphology, i.e., color, shape, bulbous suspensor, germination shield, etc. Spores were then smeared with PVLG and Melzer reagent on an object glass and crushed gently to prevent damage to the spore. The spore reaction to Melzer reagent was recorded using a stereomicroscope (Schenck and Perez 1990; Brundrett et al. 1996; INVAM 2019). The spores of MV 5, MV 17, and MV 18 were also inoculated on the root of three-day germinated maize seeds and then planted in a plastic pot with a volume of $750 \mathrm{~mL}$ containing sterilized river sand. The planted pot was kept for 1 month in the greenhouse and watered every day and fertilized with $20 \mathrm{~mL}$ of $2 \mathrm{~g} \mathrm{~L}^{-1}$ urea solution. After one month, the maize roots were cut and stained with trypan blue dye and the AMF structures inside the roots were observed under a compound microscope.
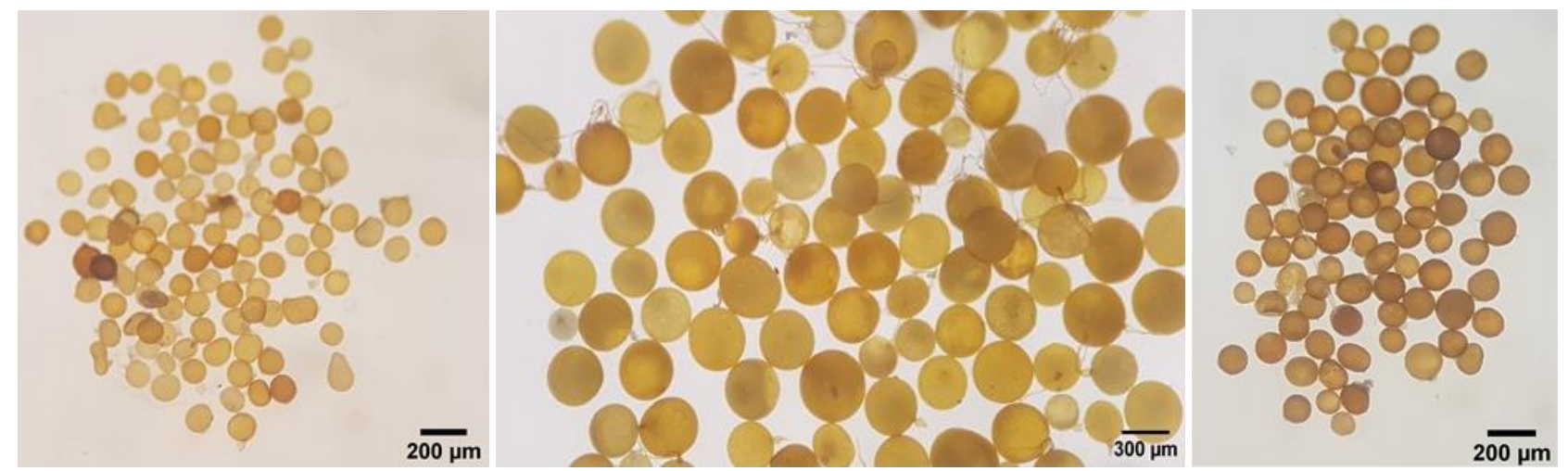

Figure 1. The AMF spores from the Plantation Production Laboratory, Lampung University, Indonesia. A. MV 5; B. MV 17; C. MV 18. Observation under stereomicroscopes with a magnification of $45 \mathrm{x}$ 


\section{Molecular analysis Spore isolation}

AMF spores were isolated using wet sieving and decanting methods. Ten healthy spores were selected and placed in a Petri dish containing $30 \mathrm{~mL}$ of $0.05 \%$ Tween 20 , then treated in an ultrasonic cleaner (Elmasonic S 60 $[\mathrm{H}])$ for 10 seconds and repeated three times. One of the best spores was transferred into sterile distilled water in a Petri dish and treated with ultrasonic cleaner (Elmasonic S $60[\mathrm{H}])$ for 10 seconds. The process was repeated thrice to ensure that the obtained spore was clean and dirt-free (Brundrett et al. 1996; Schwarzott and Schüßler 2001).

The free-debris spores were put into a $0.2 \mathrm{~mL}$ sterile microtube. Next, $20 \mu \mathrm{L}$ Instagene Matrix (BIORAD) was added to each spore in a microtube and crushed with sterile blunt pipette tips. The samples were then processed in Thermal Cycler, which was heated at $56^{\circ} \mathrm{C}$ for $30 \mathrm{~min}$ followed by $10 \mathrm{~min}$ at $95^{\circ} \mathrm{C}$. After that, the samples were spun down. The $15 \mu \mathrm{L}$ supernatant was taken and transferred into a new sterile microtube and used as the template for DNA analysis (modified Schwarzott and Schüßler 2001; Redecker 2020).

\section{DNA extraction}

PCR amplification

Polymerase chain reaction (PCR) was performed using a SensoQuest (SenseoQuest GmbH, Germany) thermal cycler machine to amplify partial $18 \mathrm{~S}$ rRNA fragment of AM fungi by nested PCR (Lee et al. 2008). The first PCR was conducted using universal primers NS1 (5'-GTA GTC ATA TGC TTG TCT C-3') and reverse primer NS4 (5'CTT CCG TCA ATT CCT TTA AG-3') with $25 \mu \mathrm{L}$ of total volume reaction. The PCR reaction consisted of $1 \mu \mathrm{L}$ of the DNA template, $12.5 \mu \mathrm{L}$ of MyTaq $^{\text {TM }}$ Red Mix (Bioline, USA), $1.25 \mu \mathrm{L}$ of $10 \mu \mathrm{M}$ NS1 primer, $1.25 \mu \mathrm{L}$ of $10 \mu \mathrm{M}$ NS4 primer, and was adjusted to the volume reaction to $25 \mu \mathrm{L}$ by adding $9 \mu \mathrm{L}$ of sterilized distilled water.

PCR amplification was achieved with one cycle of an initial denaturation at $95^{\circ} \mathrm{C}$ for 4 minutes followed by 30 cycles containing: denaturation at $95^{\circ} \mathrm{C}$ for $1 \mathrm{~min}$, annealing at $50^{\circ} \mathrm{C}$ for $1 \mathrm{~min}$, extension at $72^{\circ} \mathrm{C}$ for $1 \mathrm{~min}$, and one cycle for a final extension at $72^{\circ} \mathrm{C}$ for $5 \mathrm{~min}$. The PCR product of the first PCR was used as the DNA template for the second PCR using AMF specific primers AML1 (5'-ATC AAC TTT CGA TGG TAG GAT AGA3') and AML2 (5'-GAA CCC AAA CAC TTT GGT TTC C-3') for 32 cycles, one cycle for an initial denaturation at $95^{\circ} \mathrm{C}$ for $5 \mathrm{~min}$ followed by 30 cycles containing denaturation at $95^{\circ} \mathrm{C}$ for $1 \mathrm{~min}$, annealing at $58^{\circ} \mathrm{C}$ for 1 min, extension at $72^{\circ} \mathrm{C}$ for $1 \mathrm{~min}$ and one cycle for a final extension at $72^{\circ} \mathrm{C}$ for $5 \mathrm{~min}$. The PCR products were further analyzed in $0,8 \%$ agarose gel for electrophoresis (Invitrogen, USA). After that, $1 \mu \mathrm{L}(10 \mathrm{mg} / \mathrm{mL})$ of Ethidium Bromide was added, homogenized, and poured into the gel tank. The process was employed at $55 \mathrm{~V}$ for 60 min, and the result was visualized under a DigiDoc UV trans-illuminator (UVP, USA). The secondary PCR products were sent to $1^{\text {st }}$ Base, Malaysia, for sequencing (Lee et al. 2008).

\section{Sequence analysis}

Sequence editing was performed using CodonCode Aligner software (CodonCode Corporation, Dedham, USA) to ensure the accuracy of generated DNA. Every DNA sequence was assigned to a particular taxon by comparing it with the nucleotide sequences in GenBank database NCBI using Basic Local Alignment Search Tools (BLAST) (https://blast.ncbi.nlm.nih.gov/Blast.cgi). Sequence alignment was performed using the ClustalW program (Thompson et al. 1994) embedded in MEGAX (Tamura et al. 2013; Kumar et al. 2018). Based on the aligned sequences, a phylogenetic tree was reconstructed using MEGAX with neighborjoining (NJ) algorithms. Paraglomus occultum (C. Walker) J.B. Morton \& D. Redecker was used as an outgroup.

\section{RESULTS AND DISCUSSION}

\section{Morphology identification}

Results showed that the identification of AMF could be successfully performed by morphological characters. Results showed that MV 5, MV 17, and MV 18 belonged to the genus of Acaulospora, Gigaspora, and Glomus, respectively (Table 1). All isolates were able to infect maize roots indicated by the presence of mycorrhiza structures, namely hyphae, vesicles, and auxiliary cells.

Table 1. Morphological characters of MV 5, MV, 17, and MV 18 isolates.

\begin{tabular}{lccc}
\hline \multicolumn{1}{c}{ Taxonomic criteria } & & Description & MV 18 \\
\hline Isolate & MV 5 & MV 17 & Globose, subglobose \\
Shape & Globose & Globose, subglobose & $>45 \mu \mathrm{m}-<250 \mu \mathrm{m}$ \\
Size & $>45 \mu \mathrm{m}-<250 \mu \mathrm{m}$ & $>90 \mu \mathrm{m}-<500 \mu \mathrm{m}$ & yellow $(20-80-20)$ to brown \\
Color* & Brownish-yellow $(0-60-10)$ & Brownish-yellow $(0-90-0)$ & $(10-100-0)$ \\
& & & Absent \\
Sporocarp & Absent & Absent & Absent \\
Sporiferous Saccule & Present & Absent & Absent \\
Bulbose suspensor (BS) & Absent & Present & Absent \\
Auxiliary Cells (AC) & Absent & Present & Absent \\
Germination Shield & Absent & Absent & Negative \\
Melzer's reaction & Positive (Inner wall of spore is & Positive (the whole spore color & changed) \\
Genus & darker than the outer wall) & Acaulospora sp. & Gigaspora sp. \\
\hline
\end{tabular}

Note: *) \% CYM according to Brundrett et al. (1996); ${ }^{\#)}$ Spore was located next to the neck of Sporiferous saccule 
Based on the morphological characters, MV 5 spores can pass through a $250 \mu \mathrm{m}$ sieve and can be collected at 45 $\mu \mathrm{m}, 90 \mu \mathrm{m}$, and $150 \mu \mathrm{m}$ sieves during the wet sieving process. It has a brownish yellow color (0-60-10), and a sporiferous saccule lies on the spore's wall (Figure 2.A, a typical spore of the genus Acaulospora (Budi and Dewi 2016; Walker et al. 2018). In the Melzer solution, the spores gave a positive reaction which was indicated by a change in the spore color where the inner wall of the MV 5 spore turned out to be darker than the outer wall (Figure 2.B). This reaction is similar to the one described by Schenk and Perez (1990) in that the genus Acaulospora has a darker color in the inner wall than the outer wall after being treated with Melzer solution. Spores of MV 5 were also successfully colonized the maize roots system as hyphae, and vesicle structures were observed after root staining in Trypan Blue dye. Hyphae and vesicles are globose to oval in shape (Figure 3). The internal hyphae of mycorrhiza from the genus Acaulospora form vesicles within the root cortex (Oehl et al. 2011; Walker et al. 2018).

AMF colonization begins with the pre-infection stage, where the spores germinate into a symbiotic phase to form an appressorium (Souza 2015). The infection stage begins when the appressoria penetrate the plant roots and form internal hyphae, finely branched hyphae called arbuscular inside the cortical cell. Arbuscular hyphae are highly branched and form tree-like structures that serve as sites for nutrient and carbon exchange between the fungus and host (Smith and Read 2008; Schüßler and Walker 2011). However, arbuscular does not last long because it will degrade and provide $\mathrm{P}$ nutrients to the host plant (Brundrett et al. 1996; Smith and Read 2008; Souza 2015). Therefore, we cannot observe this structure in this study.

Besides arbuscular, vesicles are also formed in the cells of the root cortex and have a function as a storage organ. Vesicles are transforming structures of hyphae within the root cortex cells, in which terminal hyphae swell and grow (Redecker et al. 2013; Müller et al. 2017). Vesicles contain glycogen and lipids as a source of energy for fungi (Keymer et al. 2017). As the infection stage occurs, the hyphae grow extensively outside the root, known as external hyphae, forming a network that is responsible for nutrient uptake and transporting them from the soil to the roots (Walker et al. 2018).

In the wet sieving method, the spore of MV 17 (Gigaspora) can pass through the $500 \mu \mathrm{m}$ sieve and be found in $90 \mu \mathrm{m}, 150 \mu \mathrm{m}$, and $250 \mu \mathrm{m}$ sieves. It indicated that the spore size of MV17 was in the range of $>90-<500$ $\mu \mathrm{m}$. Arbuscular mycorrhizae of the genus Gigaspora has a relatively large spore size compared to other genera. The approximate size of the Gigaspora spore was reported to be around $125 \mu \mathrm{m}$ to $600 \mu \mathrm{m}$ (Oehl et al. 2008; Morton and Msiska 2010). The size of the spores changes with age. The young spores are small and gradually enlarge until they reach their maximum size when the spores are mature (Souza 2015).

The MV 17 spore characters were presented in Table 1 to correspond to its common characteristics, with yellow, greenish-yellow, brownish yellow to yellowish-brown
(Morton and Msiska 2010; Souza 2015). Spores of this genus (Gigaspora) have a special character, such as bulbous suspensor (Figure 4.A) without germination shields (Walker et al. 2018). This special character was observed in the MV 17 isolate which leads us to conclude that this isolate belongs to the genus Gigaspora. According to Oehl et al. (2008), spores of the genus Gigaspora are developed by forming small spheres on bulbous suspensors. Afterward, the small spheres develop until they reach their maximum size and eventually form spores called azygospores (Morton and Benny 1990; Schenk and Perez 1990; Souza 2015). In addition, the spore of MV 17 gave a positive reaction to the Melzer solution, where the entire spore color changed to a darker color (Figure 4.B). The Melzer results also corresponded with other studies where the positive reaction occurred in all spores (Oehl et al. 2008; Souza 2015).

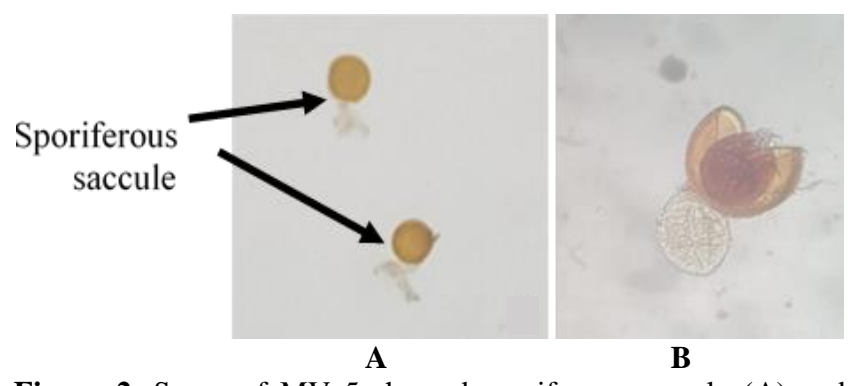

Figure 2. Spore of MV 5 showed sporiferous saccule (A) and MV5 spore in Melzer solution (B).

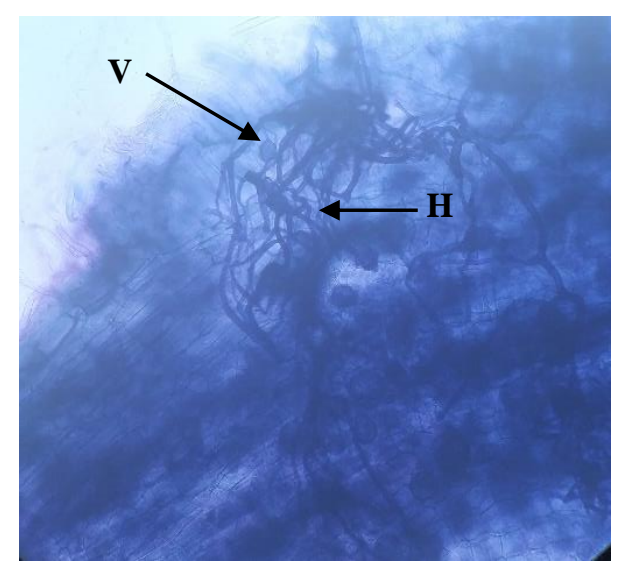

Figure 3. Colonization of maize root by MV 5, the presence of hyphae $(\mathrm{H})$, and vesicles $(\mathrm{V})$
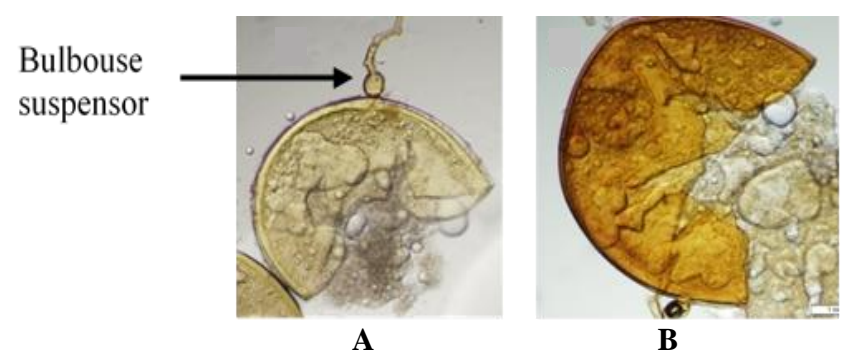

Figure 4. Spore of MV 17 isolate in PVLG solution showing bulbous suspensor (A) and spore's color in Melzer solution (B) 
This study indicated that MV 17 could colonize the root system of maize as hyphae and auxiliary cells were found in maize root (Figure 5). However, the vesicle was not observed. Auxiliary cells are typical characters that are only found in the genus Gigaspora and Scutellospora. Therefore, they can be used as a trait to identify them (Oehl et al. 2011; Souza 2015). Other studies (Khade 2011; Redecker et al. 2013) also reported that the genus Gigaspora formed auxiliary cells in external hyphae but did not form vesicles in the internal hyphae.

Based on the characters of MV 18, it could be identified as Glomus. Spores can pass through a $250 \mu \mathrm{m}$ sieve and be collected from a $45 \mu \mathrm{m}$ to $150 \mu \mathrm{m}$ (in the wet sieving process) which was aligned with the spore size of the genus Glomus in the range of 20-400 $\mu \mathrm{m}$ (Souza 2015). The reaction with Melzer's reagent gave negative results, which meant no color change when spores were crushed in Melzer solution. MV 18 spore has a globose, subglobose, and range in color from yellow to brown (10-100-0) (Figure 6) (Brundrett et al. 1996). Souza (2015) described that spore from Glomus has yellow, brownish yellow, yellowish-brown, brown, old brown, and blackish colors. We also observed that the spore of MV 18 isolate has typical subtending hyphae as it develops from the hyphal terminus and further enlarged to its maximum size, known as chlamydospore (Oehl et al. 2011; Souza 2015). In the root cortex, internal hyphal structures and vesicles were also observed (Figure 7). No auxiliary cell was found (Walker et al. 2018). Hyphae have an important role in the uptake of nutrients and water in the soil and transfer them to plant roots, while vesicle is a mycorrhizal structure emerging from hyphae and serves as a temporary storage organ also observed in MV 18 (Glomus) (Redecker et al. 2013). A vesicle has a round shape to oval, thin-walled and balloon-like structures (Souza 2015; Walker et al. 2018).

\section{Molecular identification}

Internal transcribed spacer (ITS) sequences have been used extensively to reveal phylogenetic relationships to identify glomalean fungi (Schwarzott and Schüß ler 2001; Badotti et al. 2017). However, due to the high degree of ITS variation within AMF species, it is difficult to find distinct features of closely related AMF species (Krüger et al. 2012; Victorino et al. 2020). Therefore, the SSU rRNA gene of AMF has been the best option to use for AMFspecific primers as it is less variability compared to ITS, is highly conserved, and has high specificity of the primer combination (Lee et al. 2008; Lekberg et al. 2018; PerezLamarque et al. 2020).

The success of PCR amplification was evaluated qualitatively by agarose gel as shown in Figure 8 . It showed that all mycorrhiza isolates have a thick and clean band around $800 \mathrm{bp}$ DNA in size. It indicates that the primer used in the PCR process successfully amplified specific DNA sites for these 3 isolates. Lee et al. (2008) reported that AML 1 and AML 2 were primers that amplified the AMF SSU rRNA gene of an 800 bp length sequence. They are highly sensitive detection and specific primer towards AMF, thereby avoiding nonspecific amplification (Lee et al. 2008; Arofatullah et al. 2019; Kobae et al. 2019).

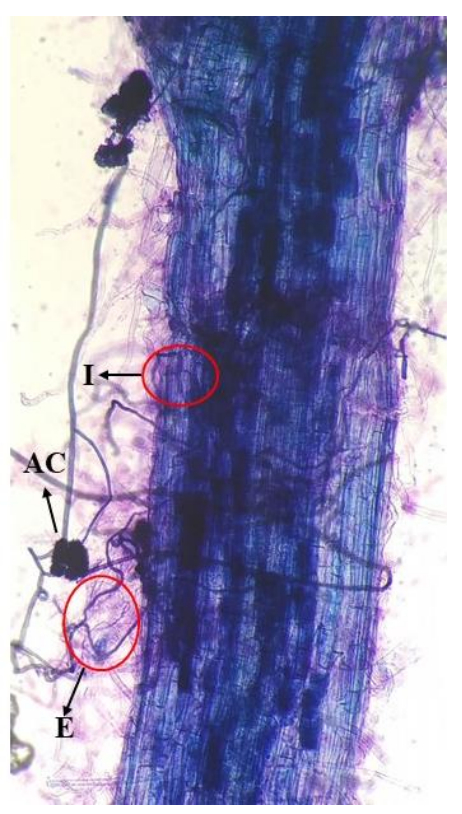

Figure 5. Colonization of maize root by MV 17 showing the presence of auxiliary cells (AC) in external (E) and internal hyphae (I) without vesicle.

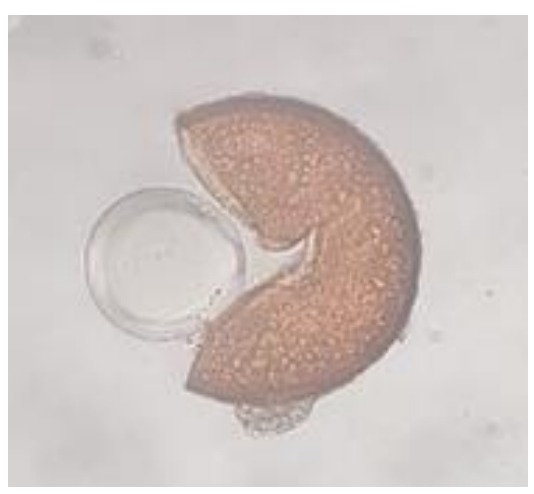

Figure 6. Spore of MV18 isolate after crushing in PVLG solution.

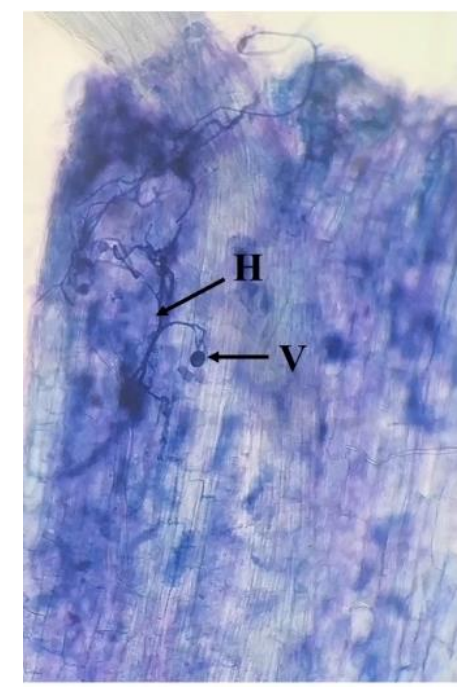

Figure 7. Structure of MV 18 colonization in maize's roots. Internal hyphae $(\mathrm{H})$ and vesicle $(\mathrm{V})$ were observed 


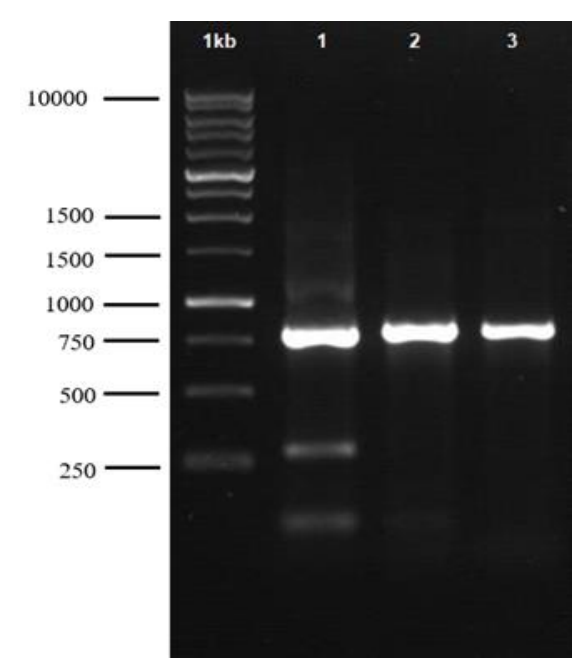

Figure 8. Electrophoresis of PCR product on agarose gel, 1) MV 17 isolate; 2) MV 18 isolate; 3) MV 5 isolate

To evaluate the success rate of species identification, the results of morphological identification were compared to the results of molecular identification using Basic Local Alignment Search Tools (BLAST-n). All AMF isolates had a match between morphological and molecular identification at the species level, with an identity value of $100 \%$. Identity value is the similarity percentage of the input DNA sequence with the DNA sequence in GenBank. A high identity value indicates a high nucleotide sequence match. The alignment of the sequence using BLASTn showed that the MV5 isolate, which was morphologically identified as Acaulospora sp., had high similarity (ident:
98,12\%) to Acaulospora longula Spain \& N.C.Schenck with a query cover value of $100 \%$. The MV 17 isolate, which was morphologically identified as Gigaspora sp., had high similarity (ident: 99,86\%) to Gigaspora margarita W.N.Becker \& I.R.Hall, and the value of query cover was $100 \%$. The third isolate, MV 18, which was morphologically identified as Glomus sp., had the highest similarity (ident: $100 \%$ ) to Glomus etunicatum W.N.Becker $\&$ Gerd. (synonym Claroideoglomus etunicatum [Schüßler and Walker 2010]), with the query cover value of $100 \%$. The BLAST identification results are shown in Table 2.

The phylogenetic trees were constructed based on multiple sequence alignments from sequences of three AMF isolates and GenBank (NCBI) data sequences using the Kimura 2-parameter method. This method uses transitional and transversion parameters to calculate the percentage difference in genetic distance between samples (Nei and Kumar 2000). The method used is NeighborJoining (NJ) with a bootstrap value of 1000x. This method effectively quantifies the nucleic acid differences used in identifying species and assessing similarities. The phylogenetic tree analysis aims to confirm the relationship among isolates in the research sample. The expected phylogenetic tree is the one that can group samples based on taxonomic similarity at the species, genus, and family levels and is confirmed by the high value of bootstrap value in the phylogenetic tree branches. The phylogenetic tree shown in Figure 9 showed that the bootstrap values range from 56-100. The higher the bootstrap value, the less likely the branch tree or taxon will change; thus, the phylogeny has a firm consistency and high confidence level (Prasetya et al. 2011; Sharuddin and Muda 2015).

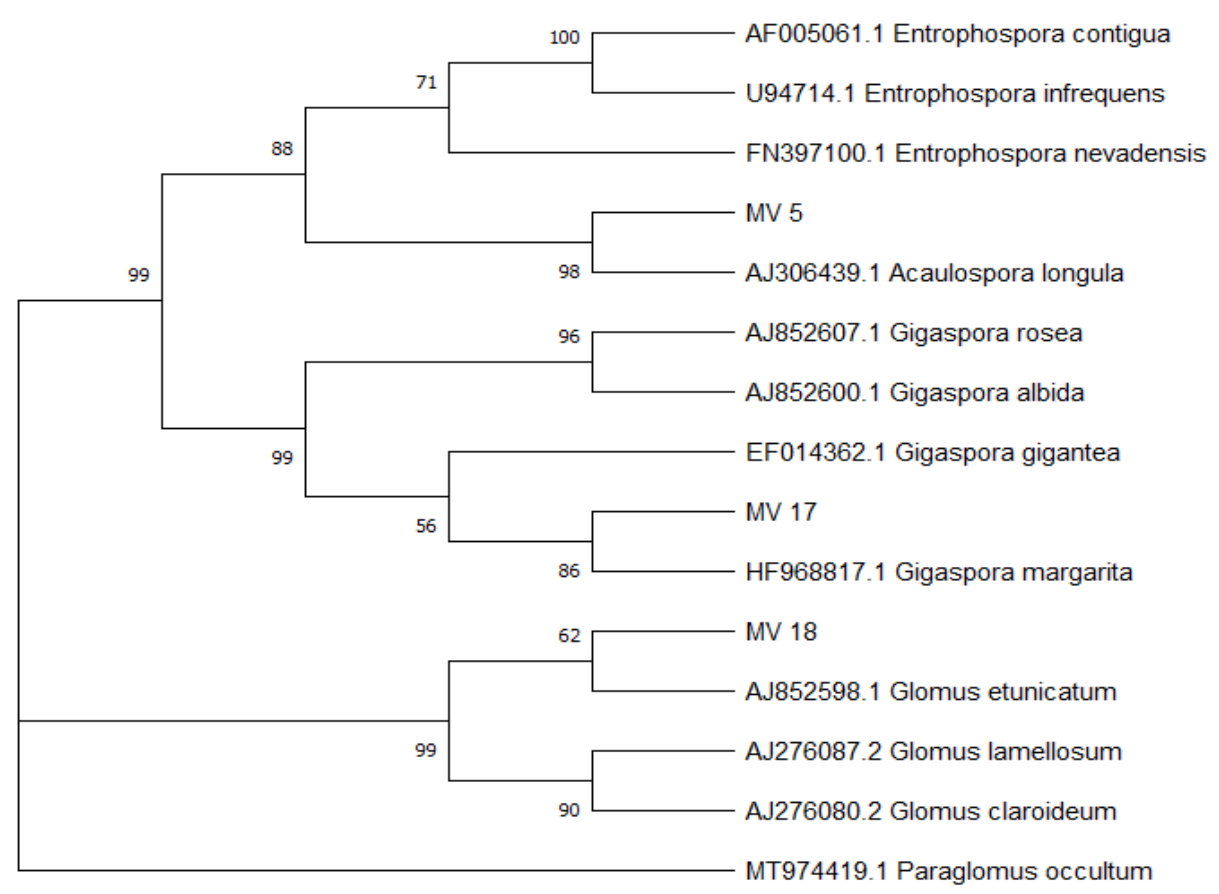

Figure 9. Phylogenetic tree of MV 5, MV 17, and MV 18 
Table 2. Blast identification result

\begin{tabular}{ccccc}
\hline Sample & Morphology identification & Molecular identification (BLAST) & \% Query cover & \% Ident \\
\hline MV 5 & Acaulospora sp. & Acaulospora longula & 100 & 98,12 \\
MV 17 & Gigaspora sp. & Gigaspora margarita & 100 & 99,86 \\
MV 18 & Glomusp. & Glomus etunicatum & 100 & 100 \\
\hline
\end{tabular}

The constructed phylogenetic tree separated the three AMF isolates from their outgroup, $P$. occultum. The phylogenetic tree in Figure 9 showed that the MV 5 isolate formed the same cluster as A. longula and was on a different clade with the Entrophospora genus. The MV 17 isolate formed the same cluster with the Gigaspora genus and on the same clade with $G$. margarita. The phylogenetic tree also showed that MV 18 isolate was on the same clade with G. etunicatum (synonym Claroideoglomus etunicatum).

Identification of the three AMF isolates based on morphology complemented the identification based on molecular (species level) (Table 2). Therefore, we have more detailed, valid data, high confidence, and stronger results by conducting the two methods. Nonomura et al. (2011) stated that combining the results from two methods is the best approach to identify AMF taxonomy.

Based on morphological identification, it can be concluded that MV 5, MV 17, and MV 18 isolates have characteristics belonging to the genera Acaulospora, Gigaspora, and Glomus genus, respectively, while identification based on molecular analysis showed that MV 5, MV 17, and MV 18 isolates are included in the species of A. longula, G. margarita, and G. etunicatum (synonym Claroideoglomus etunicatum), respectively. The results of this study would be useful for further research when using these three isolates due to the detailed information on the characteristics and species information.

\section{ACKNOWLEDGEMENTS}

The author would like to thank LPPM Universitas Lampung, Indonesia and PT Myco Agro Lestari, Jakarta, Indonesia for their financial support to carry out this research.

\section{REFERENCES}

Arofatullah NA, Widianto D. 2019. Molecular identification and in vitro propagation of arbuscular mycorrhiza from tea plant rhizosphere. Curr Res Environ Appl Mycol 9 (1): 92-102. DOI: 10.5943/cream/9/1/10.

Badotti F, de Oliveira FS, Garcia CF, Vaz ABM, Fonseca PLC, Nahum LA, Oliveira G, Góes-Neto A. 2017. Effectiveness of ITS and subregions as DNA barcode markers for the identification of Basidiomycota (Fungi). BMC Microbiol 17 (1): 1-12. DOI: 10.1186/s12866-017-0958-x.

Budi WS, Dewi PA. 2016. Keanekaragaman fungi mikoriza arbuskular di bawah tanaman jabon (Anthocephalus cadamba) di Madiun, Jawa Timur. Jurnal Silvikultur Tropika 7 (3): 146-152. [Indonesian]
Bücking H, Kafle A. 2015. Role of arbuscular mycorrhizal fungi in the nitrogen uptake of plants: current knowledge and research gaps. Agronomy 5 (4): 587-612. DOI: 10.3390/agronomy5040587.

Brundrett M, Bougher N, Dell B, Grove T, Malajczuk N. 1996. Working with mycorrhizas in forestry and agriculture. Australian Centre for International Agricultural Research, Canberra.

Chen M, Arato M, Borghi L, Nouri E, Reinhardt D. 2018. Beneficial services of arbuscular mycorrhizal fungi-from ecology to application. Front Plant Sci 9: 1270. DOI: 10.3389/fpls.2018.01270.

Covacevich F, Hernández Guijarro K, Crespo EM, Lumini E, Rivero Mega MS, Lugo MA. 2021. Arbuscular mycorrhizal fungi from argentinean highland puna soils unveiled by propagule multiplication. Plants 10 (9): 1803.

Duc NH, Csintalan Z, Posta K. 2018. Arbuscular mycorrhizal fungi mitigate negative effects of combined drought and heat stress on tomato plants. Plant Physiol Biochem 132: 297-307. DOI: 10.1016/j.plaphy.2018.09.011.

Hu S, Hu B, Chen Z, Vosátka M, Vymazal J. 2021. Arbuscular mycorrhizal fungi modulate the chromium distribution and bioavailability in semi-aquatic habitats. Chem Eng J 420: 129925. DOI: 10.1016/j.cej.2021.129925.

Ijdo M, Cranenbrouck S, Declerck S. 2011. Methods for large-scale production of AM fungi: past, present, and future. Mycorrhiza 21 (1): 1-16. DOI: 10.1007/s00572-010-0337-z.

INVAM. 2019. Permanent slides: Mounting Spores on Glass Slides. West Virginia University, International Culture Collection of (Vesicular) Arbuscular Mycorrhizal Fungi. https://invam.wvu.edu/ [30-062021].

Keymer A, Pimprikar P, Wewer V, Huber C, Brands M, Bucerius SL, Delaux PM, Klingl V, Röpenack-Lahaye EV, Wang TL, Eisenreich W, Dörmann P, Parniske M, Gutjahr C. 2017. Lipid transfer from plants to arbuscular mycorrhiza fungi. eLife 6: e29107. DOI: 10.7554/eLife.29107.

Khade SW. 2011. New characteristics for morphotaxonomy of Gigaspora species belonging to arbuscular mycorrhizal fungi. J Plant Develop 18: 71-80.

Kobae Y, Ohtomo R, Morimoto S, Sato D, Nakagawa T, Oka N, Sato S. 2019. Isolation of native arbuscular mycorrhizal fungi within young thalli of the liverwort Marchantia paleacea. Plants 8 (6): 142. DOI: 10.3390/plants8060142.

Krüger M, Krüger C, Walker C, Stockinger $\mathrm{H}$, Schüßler A. 2012. Phylogenetic reference data for systematics and phylotaxonomy of arbuscular mycorrhizal fungi from phylum to species level. New Phytol 193 (4): 970-984. DOI: 10.1111/j.1469-8137.2011.03962.x.

Kumar S, Stecher G, Li M, Knyaz C, Tamura K. 2018. MEGA X: Molecular evolutionary genetics analysis across computing platforms. Mol Biol Evol 35 (6): 1547-1549. DOI: 10.1093/molbev/msy096.

Lee J, Lee S, Young JPW. 2008. Improved PCR primers for the detection and identification of arbuscular mycorrhizal fungi. FEMS Microbiol Ecol 65 (2): 339-349. DOI: 10.1111/j.1574-6941.2008.00531.x.

Lekberg Y, Vasar M, Bullington LS, Sepp SK, Antunes PM, Bunn R, Larkin BG, Öpik M. 2018. More bang for the buck? Can arbuscular mycorrhizal fungal communities be characterized adequately alongside other fungi using general fungal primers? New Phytol 220 (4): 971-976. DOI: 10.1111/nph.15035.

Melo CD, Walker C, Krüger C, Borges PAV, Luna S, Mendoça D, Fonseca HMAC, Machado AC. 2019. Environmental factors driving arbuscular mycorrhizal fungal communities associated with endemic woody plant Picconia azorica on native forest of Azores. Ann Microbiol 69 (13): 1309-1327. DOI: 10.1007/s13213-019-01535-x.

Morton JB, Benny GL. 1990. Revised classification of arbuscular mycorrhizal fungi (Zygomycetes): a new order, Glomales, two new suborders, Glomineae and Gigasporineae, and two families, Acaulosporaceae and Gigasporaceae, with an emendation of Glomaceae. Mycotaxon 37: 471-491. 
Morton JB, Msiska Z. 2010. Phylogenies from genetic and morphological characters do not support a revision of Gigasporaceae (Glomeromycota) into four families and five genera. Mycorrhiza 20 (7): 483-496. DOI: 10.1007/s00572-010-0303-9.

Müller A, Ngwene B, Peiter E, George E. 2017. Quantity and distribution of arbuscular mycorrhizal fungal storage organs within dead roots. Mycorrhiza 27 (3): 201-210. DOI: 10.1007/s00572-016-0741-0.

Nei M, Kumar S. 2000. Molecular evolution and phylogenetics. Oxford University Press, Oxford.

Nonomura N, Kawada Y, Minamiya Y, Hayakawa H, Fukuda T, Kang Y, Sakurai K. 2011. Molecular identification of arbuscular mycorrhizal fungi colonizing Athyrium yokoscense of the Ikuno Mine Site, Japan.
Jpn
Bot
86
(2): http://www.jjbotany.com/pdf/JJB_086_073_081.pdf [26 062021]

Oehl F, de Souza FA, Sieverding E. 2008. Revision of Scutellospora and description of five new genera and three new families in the arbuscular mycorrhiza-forming Glomeromycetes. Mycotaxon 106 311-360.

Oehl F, Sieverding E, Palenzuela J, Ineichen K, da Silva GA. 2011. Advances in Glomeromycota taxonomy and classification. IMA Fungus 2 (2): 191-199. DOI: 10.5598/imafungus.2011.02.02.10.

Perez-Lamarque B, Öpik M, Maliet O, Silva ACA, Selosse M, Martos F, Morlon H. 2020. Global drivers of obligate mycorrhizal symbionts diversification. bioRxiv (2020). DOI: 10.1101/2020.07.28.224790.

Prasetya CAB, Anderson C. 2011. Assessment of the effect of longterm tillage on the arbascular mycorthiza colonization of vegetable crop grown in Andisol. Agrivita 33 (1): 85-92.

Prasetya H, Saefuddin A, Muladno. 2011. Performance comparison between kimura 2-parameters and jukes-cantor model in constructing phylogenetic tree of neighbour joining. In Forum Statistika dan Komputasi 16 (1): 8-16.

Redecker D, Schüßler A, Stockinger H, Stürmer SL, Morton JB, Walker C. 2013. An evidence-based consensus for the classification of arbuscular mycorrhizal fungi (Glomeromycota). Mycorrhiza 23 (7): 515-531. DOI: 10.1007/s00572-013-0486-y.

Redecker D. 2020. Single-spore extraction for genetic analyses of arbuscular mycorrhizal fungi. In: Ferrol N, Lanfranco L (eds) Arbuscular Mycorrhizal Fungi. Methods in Molecular Biology. Humana, New York. DOI: 10.1007/978-1-0716-0603-2_8.

Rias RR, Rini MV, Yelli F. 2014. Seleksi lima isolat fungi mikoriza arbuskular untuk pembibitan kelapa sawit (Elaeis guineensis Jacq.) pada dua dosis pupuk NPK. JPPT 15 (1): 24-32. DOI 10.25181/jppt.v15i1.108. [Indonesian]

Rini MV, Pertiwi KO, Saputra H. 2017. Seleksi lima isolate fung mikoriza arbuskular untuk kelapa sawit (Elaeis guineensis Jacq.) di pembibitan. Jurnal Agrotek Tropika 5 (3): 138-143. DOI: 10.23960/jat.v5i3.1820. [Indonesian]

Rini MV, Susilowati E, Riniarti M, Lukman I. 2020. Application of Glomus sp. and a mix of Glomus sp. with Gigaspora sp. in improving the Agarwood (Aquilaria malaccensis Lamk.) seedling growth in Ultisol soil. IOP Conf Ser Earth Environ Sci 449 (1): 012004. DOI $10.1088 / 1755-1315 / 449 / 1 / 012004$
Schenk NC, Perez Y. 1990. Manual for Identification of VA Mychorrizal Fungi. $2^{\text {nd }}$ ed. Synergistic Publications, Florida.

Schüßler A, Walker C. 2010. The Glomeromycota: A Species List With New Families and New Gener. The Glomeromycota: A Species List With New Families and New Gener.

Schüßler A, Walker C. 2011. 7 Evolution of the 'Plant-Symbiotic' Fungal Phylum, Glomeromycota. In: Pöggeler S, Wöstemeyer J (eds) Evolution of Fungi and Fungal-Like Organisms. The Mycota (A Comprehensive Treatise on Fungi as Experimental Systems for Basic and Applied Research). Springer, Heidelberg, Berlin, Germany. DOI: 10.1007/978-3-642-19974-5 7.

Schwarzott D, Schüßler A. 2001. A simple and reliable method for SSU rRNA gene DNA extraction, amplification, and cloning from single AM fungal spores. Mycorrhiza 10 (2001): 203-207. DOI: 10.1007/PL00009996.

Selvakumar G, Shagol CC, Kang Y, Chung B, Han SG, Sa TM. 2018 Arbuscular mycorrhizal fungi spore propagation using single spore as starter inoculum and a plant host. J Appl Microbiol 124 (6): 15561565. DOI: $10.1111 /$ jam. 13714.

Sharuddin S, Muda N. 2015. Performance Comparison between Bootstrap and Multiscale Bootstrap for Assessing Phylogenetic Tree for RNA polymerase. Sains Malaysiana 44 (11): 1643-1651.

Smith SE, Read DJ. 2008. Mycorrhizal Symbiosis 3rd ed. Academic Press, San Diego.

Smith SE, Smith FA. 2012. Fresh perspective on the roles of arbuscular mycorrhizal fungi in plant nutrition and growth. Mycologia 104 (1): 1-13. DOI: $10.3852 / 11-229$.

Souza T. 2015. Handbook of Arbuscular Mycorrhizal Fungi. Springer International Publishing, Switzerland. DOI: 10.1007/978-3-31924850-9.

Syafruddin S, Syakur S, Teti A. 2016. Propagation techniques of mycorrhizal bio-fertilizer with different types of mycorrhiza inoculant and host plant in Entisol Aceh. Intl J Agric Res 11 (2): 69-76. DOI: 10.3923/ijar.2016.69.76.

Tamura K, Stecher G, Peterson D, Filipski A, Kumar S. 2013. MEGA6: Molecular Evolutionary Genetics Analysis version 6.0. Mol Biol Evol 30 (12): 2725-2729. DOI: 10.1093/molbev/mst197.

Thompson JD, Higgins DG, Gibson TJ. 1994. CLUSTAL W: improving the sensitivity of progressive multiple sequence alignment through sequence weighting, position-specific gap penalties and weight matrix choice. Nucleic Acid Res 22 (22): 4673-80. DOI: 10.1093/nar/22.22.4673.

Victorino ÍMM, Berruti A, Orgiazzi A, Voyron S, Bianciotto V, Lumini E. 2020. High-Throughput DNA Sequence-Based Analysis of AMF Communities. In: Ferrol N, Lanfranco L (eds) Arbuscular Mycorrhizal Fungi. Methods in Molecular Biology. Humana, New York. DOI: 10.1007/978-1-0716-0603-2_9.

Walker C, Harper CJ, Brundrett MC, Krings M. 2018. Looking for arbuscular mycorrhizal fungi in the fossil record: An Illustrated Guide. In: Krings M, Harper CJ, Cúneo NR, Rothwell GW (eds) Transformative Paleobotany. Academic Press. DOI: 10.1016/B978-012-813012-4.00020-6. 